\title{
The relationship of the dimensions of job satisfaction to job performance: A case study of a multinational company in Lesotho
}

\author{
Lineo Rosina Ratia (MBA)a, Şule Erdem Tuzlukaya ${ }^{b *}$ \\ ${ }^{a}$ Atılım University, MBA, Ankara, Turkey, Lineo La guitara Ratia, r.laguitara@gmail.com \\ $b^{*}$ Atılım University, Faculty of Management, Department of Management, Ankara, Turkey, sule.tuzlukaya@atilim.edu.tr \\ ${ }^{*}$ Corresponding author
}

Received: 11 July 2019, revised: 1 August 2019, accepted: 5 August 2019, published: 8 August 2019.

\begin{abstract}
This study aims to investigate job satisfaction and job performance relationship in a multinational company in the least developed country. This study also examines the relationship between job satisfaction dimensions and job performance of the employees. Data were collected from a sample of the leading multinational telecommunication company in Lesotho. The aforementioned relationships were tested based on correlation analysis and multiple regression analysis. Although there is an extensive body of research regarding job satisfaction and job performance relationship, the research concerning the two variables in multinational companies in the least developed countries is rather few and overlooked. The results demonstrate that there is empirical support for the hypothesized relationships except for operating conditions sub-dimension of job satisfaction.
\end{abstract}

Keywords: job satisfaction, job performance, job satisfaction dimensions, multinational company, least developed country, Lesotho

JEL codes: $M 10, M 120, M 50$

\section{INTRODUCTION}

A high level of employee performance leads to the organization's productivity which in turn leads to success (Wattoo et al., 2019). Productivity through effectiveness and efficiency has always been of paramount importance for any organization to achieve various organizational goals (Zinal, 2016; Imran et al., 2015; Gregory et al., 2009; Taris and Schreurs, 2009). As also stated by Zikmund et al. (2014) a dedicated, satisfied, motivated and hardworking employee is undeniably an important asset any company could have. Besides, an employee's job satisfaction is very critical in terms of overall performance. On the other hand, unsatisfied workers tend to hinder the company's process and productivity due to low morale and dissatisfaction level. Although there are several studies integrating job satisfaction and performance, few have focused on the relationship between these two variables in multinational companies in the least developed countries (Valei and Rezaei, 2016). Human resources management and the satisfaction of the employees are crucial tasks also for multinational companies (MNCs). Due to highly diversified workforce requirements, however, that is not easy to do so. Especially, in comparison to the local companies, MNCs provide huge resources that are beneficial for both economic and social development in the least developed countries (Mukul et al., 2013). Therefore, investigating the relationship between the two variables in multinational companies in the least developed countries can accept as a meaningful topic.

In light of this focus, the present paper, aims to investigate if job satisfaction influences employee's performance, in MNCs in the least developed countries. Further objectives of the study are to investigate if there is a connection between the job satisfaction dimensions (pay, promotion, supervision, fringe benefits, rewards, operating conditions, co-workers, nature of the work and communication) and job performance. To investigate the above-mentioned questions quantitative research is carried out. The research sample composes employees working in a multinational telecommunication company in Lesotho. 
Based on the research objectives above, the study was guided by the following research questions: 'Is there any correlation between job satisfaction and employees' job performance in an MNC in Lesotho? Is there any relationship between job satisfaction dimensions (co-workers, supervision, the work itself, pay and promotion, operating procedures, communication, fringe benefits, and rewards) and employees' job performance?

The rest of the article is structured as follows: First, the literature on job performance, job satisfaction and its dimensions and job performance are reviewed. This is followed by the methodology section including research method, sample, data analysis, and findings information. Finally, the conclusion provided an explanation and discussion regarding the main findings. The fundamental contribution of this study is that providing insight regarding the relationship between job performance and job satisfaction in a multinational company in the least developed country which is mainly overlooked.

\section{LITERATURE REVIEW}

\subsection{Job performance}

Job performance has been one of the most focused and studied the topic of organizational behaviour field (Pieper et al., 2019; Peng, 2014; Hellqvist, 2011; Anitha, 2014). According to Pandey, (2019, p.263) job performance is "scalable actions, behavior, and outcomes that employees engage in or bring about that is linked with and contribute to organizational goals". Job performance at the workplace is influenced by such factors as organizational and individual. According to Peng (2014), job performance can be described as the amount of work as well as quality and quantity of output, or more commonly as to how well an employee can perform the assigned tasks at the workplace. Gupta (2014) mentioned that employee performance is related to what an individual worker does or does not do. Pradhan and Jana (2016) refer to job performance as an employee's work achievement after utilizing required skills, knowledge and dedication that is linked with acquiring a meaningful work done. Similarly, Muchemi (2015) suggests the idea that employee's performance is behavioral, evaluative, episodic, and multidimensional whereas it is required to be evaluated over a period of time and composed of a set of goals (Kehoe and Wright, 2013; Singh and Jain, 2013; Javed et al., 2014). Besides the mentioned stream of job performance research, the other focus is mainly on task-related performance. FlueggeWoolf (2014) for example, focuses on the relationship between task performance and fun relationship to investigate the concept.

\subsection{Job satisfaction and dimensions}

Studies both on job satisfaction and its dimensions are abundant in the literature. Dugguh and Denies (2014) cite Locke (1976), who defines job satisfaction as a feeling of pleasure arising from a sense of achievement on one's job. According to Miah et al. (2019) and Amin et al. (2017) job satisfaction is defined as an emotional, psychological and environmental circumstance, general attitudes and feelings that workers have towards their jobs. It is highly influenced by the workers' perceptions with respect to their various task assignments. It is considered as not only the workers' general attitudes and feelings towards the job (Haile and Premanandam, 2017; Bakotić, 2016) but also, from a broader perspective, accepted as an emotional response (Singh and Jain, 2013).

Job satisfaction plays a very fundamental role in the workplace (Rosete, 2006). Therefore the employers and human resource managers to know more about it, its determinants and its overall fit into the company's goals and objectives (Javed et al., 2014; Valei and Rezaei, 2016; Singh, et al., 2019; Klaus and Cregan, 2017). To support this view Iskandar et al. (2014) state that the success of any organization depends on the workers, who enjoy doing their jobs and feel rewarded and appreciated for their contribution to the company's overall success.

According to Ahmad et al. (2012) and Valaei and Rezaei (2016), most of the researchers generally pay attention to the two most used determinants of job satisfaction which are demographic variables and work environment variables. In this study, the researchers focused on the relationship between job satisfaction and job performance by using job satisfaction survey by Spector (1994) which covers nine job satisfaction dimensions as pay, promotion, supervision, fringe benefits, contingent rewards, operating conditions, co-workers, nature of work and communication. These nine dimensions are necessary for determining job satisfaction (Greer and Singh, 2002; Hansen and Gwozdz, 2013).

\subsection{The Relationship between job satisfaction, its dimensions and job performance in the context of MNCs in Lesotho}

The relationship between job satisfaction and employees' performance has been a topic of interest for researchers for a very long time (Steel, et al., 2019; Amin et al., 2017; Singh and Jain, 2013; Haike and Premanandam, 2017). Following early theories, researchers began to investigate in-depth the relationship between the two variables using empirical investigations and potential mediators and moderators of the 
correlation between the two variables. Jin (2017) states that satisfaction causes performance, performance causes satisfaction, and rewards cause both performance and satisfaction. Garrin (2014) and Musyoka (2015) have expressed that job satisfaction leads to higher productivity, organizational responsibility and employees' physical and mental health which in turn increases performance. When workers are highly pleased with their jobs they work hard, they meet deadlines and submit high-quality work. This is also influenced by loving what they do, this means that satisfaction leads to high job performance and dedication.

Being an employee in multinational companies can prove to be enormously advantageous and helpful when it comes to gaining the right kind of exposure, wages and benefits packages, and also a work-pay balance (Omondi, 2015). These are the principal reasons why many people are increasingly drawn towards MNCs. Jin (2017) describes that multinational companies transfer managerial skills, knowledge, and practices from their country of origin to the country of operation. Especially, a lot of multinational companies from least developed economies became a fundamental part of the global economy. Abdifatah (2015) states that multinational companies often hold power over local businesses and national governments due to their different market structures, intellectual property and advancement in technology especially in the least developed countries like Lesotho ${ }^{1}$ where foreign direct investment and international businesses are the biggest employers after the government. Furthermore, Fobete (2013) underlines the importance of MNCs by stating that people are inspired to work for MNCs because of the motivating kind of competitive spirit required to propel employees forward in their professional careers. MNCs help creates a lot of well-paying jobs with good benefits for the host countries. For this reason, knowing how to keep employees satisfied will be an important tool to increase effectiveness and performance moreover satisfied employees contribute to the company's good reputation. Following this reasoning, the first hypothesis can be proposed:

$\mathrm{H} 1$ : There is a correlation between job satisfaction and the job performance of the MNC operating in Lesotho.

\subsubsection{Pay}

Most people choose to spend the majority of their adult lives in paid employment. Thus, out of all these mentioned factors pay is considered the most significant (Millian, 2013; Shields and Price, 2002). Satisfaction related to pay defines the perception and/or attitude of an employee towards it. Therefore this evaluation process is highly related to the difference between expected and received the amount of payment (Cobb, 2004). When the employees perceive positively the payment policies of the organization, their job-related performance increases. Research also stated that compared to domestic and small companies, multinational companies often offer higher and better salaries (Greer and Singh, 2002). To support this view, Jin (2017) states that the wages and salaries structures in MNCs are mostly based on various features such as educational background, work experience at other MNCs and high level of competency. Based on this, the second hypothesis can be proposed:

$\mathrm{H} 2$ : There is a significant relationship between pay and the job performance of the MNC operating in Lesotho.

\subsubsection{Promotion}

Besides salary, promotion is described as an important feature of an employee's job satisfaction (Pergamit and Veum, 1999; Cobb, 2004). It can be considered as an act of advancement for an employee into a higher position within an organization (Hansen and Gwozdz, 2013; Williams, et al., 2018). Currivan (1999) also defines promotion as a worker's movement to a better task with enhanced responsibilities, better salary, increased benefits and rewards. The expected reflection of promotion satisfaction on performance will be positive. However, as Kosteas (2011) states among the other dimensions relatively little attention has been paid to the importance of promotion. One example can be given from the study of Piekkari et al. (2005) as their study focuses on the proficiency of language as a precondition for promotion in the MNC context. Following this, the third hypothesis is proposed:

H3: There is a significant relationship between promotion and the job performance of the MNC operating in Lesotho.

\subsubsection{Relationship with supervision}

A supervisor in a workplace refers to an individual who is responsible for supervising and guiding other employees and their activities (Baharin and Sentosa, 2012). In organizational settings, a good employeesupervisor relationship is important as it affects performance (Bakotić, 2016; Wong and Laschinger, 2013).

\footnotetext{
${ }^{1}$ Lesotho (Kingdom of Lesotho) is an independent mountainous least developed country with approximately 2 million population. Least developed countries (LDCs) a list of countries that can be described as low-income, extremely vulnerable countries in terms of economy and environmental shocks.
} 
Supervision as a job satisfaction dimension is crucial also for the MNC context. Since MNCs bring along with them a wealth of knowledge and experience to the countries and companies they operate in, they facilitate also employee's personal growth and development through developing relationships with supervisors. According to Baharin and Sentosa (2012) unlike employees from domestic or local corporations, multinational companies' employees have a chance to learn not only about various cultural, political, customs or ethical norms but also different perspectives from other employees, especially from the supervisors. Besides, as De Schutter (2005) states that one of the most important decisions that multinational companies make is the choice and the selection of a manager to run the company in a foreign country which is imperative to the image, success and employees' performance. Thus, the fourth hypothesis is proposed:

$\mathrm{H} 4$ : There is a significant relationship between the supervision and the job performance of the MNC operating in Lesotho.

\subsubsection{Fringe Benefits}

Fringe benefits are such benefits considered as non-inflationary means of improving the economic conditions of employees. They refer to insurance coverage, education assistance, retirement plan contribution and all those other benefits and payments an employee receives in addition to his wages and salaries (Pan, 2015). This substitution, they can also act as substitutes for employees' wages and salaries and this substitution can increase employees' satisfaction (Pan, 2015). MNCs normally provide a substantial amount of benefits as a way of encouraging and inspiring the employees for their efforts. Based on this, the fifth hypothesis is as follows:

$\mathrm{H} 5$ : There is a significant relationship between the fringe benefits and the job performance of the MNC operating in Lesotho.

\subsubsection{Contingent Rewards}

Yousaf et al., (2014) define contingent reward as a form of motivation where employees are rewarded for doing an incredible job and for attaining their identified organizational goals. Companies normally reward their employees as a way of encouraging and motivating them to effectively complete the task assigned in a professional and timely manner (Linz and Semykina, 2012). In the MNC context, as Chiang and Birtch (2006) state that reward appreciation of reward preferences entails consideration of employee characteristics and other contextual factors beyond culture. So, the sixth hypothesis of this study is proposed as follows:

$\mathrm{H6}$ : There is a significant relationship between the contingent rewards and the job performance of the MNC operating in Lesotho.

\subsubsection{Operating Procedures}

Creswell (2012) defines a company's standard operating procedures as a written set of instructions outlining routine processes employees must follow when performing different tasks in the workplace. Thornbecke and Salike (2014) state that multinational companies not only have their standards of a running a business but they also have to follow three general procedures which are a merger with or direct acquisition of existing concerns, joint venture or sequential market entry when they want to expand and seek access to new markets. These rules and procedures are also based on each country's law and industry regulations. Based on this reasoning, the following hypothesis is proposed:

$\mathrm{H7}$ : There is a significant relationship between operating conditions and the job performance of the MNC operating in Lesotho.

\subsubsection{Relationship with co-workers}

According to Kaur (2013), a good relationship among co-workers is one of the most important factors affecting both job performance and job satisfaction. Employees seek to sustain good relationships with co-workers that will provide a positive work environment. Thus, that increases also the satisfaction level (Fok and Yeung, 2016). On the contrary, a hostile work environment with rude or unpleasant co-workers is one that usually has lower job satisfaction. In the case of multinational companies employees are exposed to broader experience by working with other employees from different racial and ethnic backgrounds, more especially if they get the opportunity to travel or work with colleagues in different parts of the world. According to Baharin and Sentosa (2012) unlike employees from domestic or local corporations, in multinational companies employees have a chance to learn not only about varied cultural, political, customs or ethical norms but also different perspectives from other employees due to the diversified work environment. Based on the above discussion, hypothesis eight is proposed:

H8: There is a significant relationship between the co-worker relationship and the job performance of the MNC operating in Lesotho. 


\subsubsection{The nature of the job}

The nature of work can be defined as the type of work an employee does which also involves an employees' workplace such as an office for administration, a construction site for buildings or bridges, an industrial site or a kitchen for cooks. Performance may be improved by better matching employees with their jobs. According to Baharin and Sentosa (2012) regarding the working environment, MNCs hire staff from different countries, with different backgrounds, cultures, and religions. This sort of dynamic and diversified environment provides employees with the opportunity to learn multiple languages, different customs and beliefs additionally; employees can engage in cultural dialogue and become informed about the outside world. A diverse environment does not only enrich a company's culture but also helps in employees' empowerment and performance since different viewpoints, skills, knowledge, and ideas lead to creativity and problem-solving skills. Thus, the ninth hypothesis of this study is proposed as follows:

$\mathrm{H} 9$ : There is a significant relationship between the nature of work and the job performance of the MNC operating in Lesotho.

\subsubsection{Communication}

Communication has an important role in terms of job performance (Piekkari et al., 2005). Communication in an organization is one of the most fundamental factors essential for the organizational functioning as employees spend a substantial amount of their time at work collecting and transferring the company's information concerning vital matters such as performance feedback, company policy, job instructions and customers' queries in MNCs. In the context of multinational companies Thahier et al. (2014) state that the world is becoming a global village which makes communication process becomes difficult due to differences in language and culture, therefore, global communication requires the use of several types of tools as companies are expanding their businesses all over the world, they need skilled people who have ability to communicate the ideas and the information of the company well. Finally, the tenth hypothesis of the study is as follows:

$\mathrm{H} 10$ : There is a significant relationship between communication and the job performance of the MNC operating in Lesotho.

Figure 1: Conceptual framework of the study

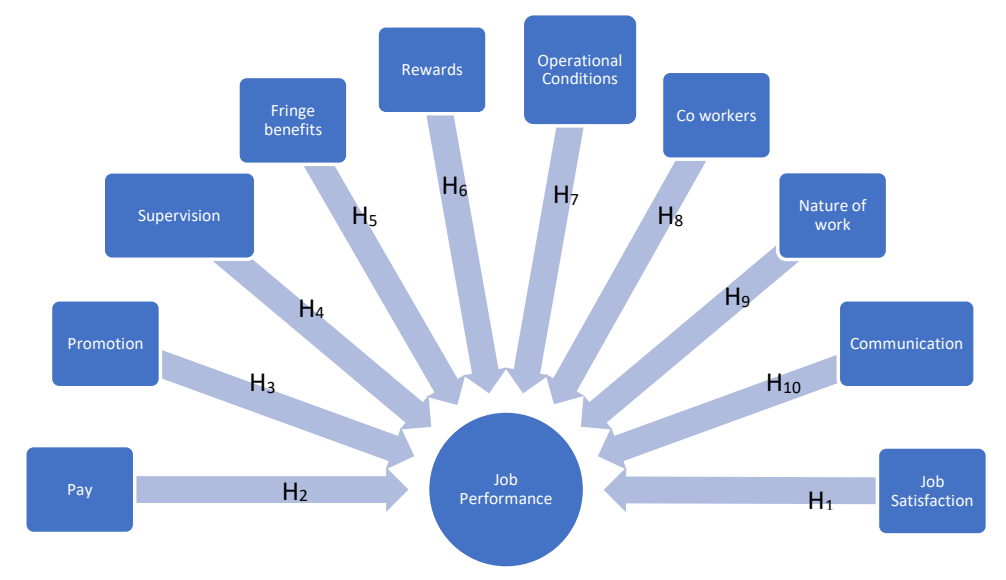

\section{METHODS}

\subsection{Research design}

The primary aim of this study is to investigate the relationship between job satisfaction and job performance in a multinational company. In this study, a quantitative research approach is carried out and the survey design is applied for data collection. 


\subsubsection{Sample}

The research is conducted in an MNC telecommunication company, established in Lesotho. The company has a total of 288 employees, 250 of these works permanently. As a sampling method and the selection of the sample size, the researcher decided to identify the 250 permanent, full-time employees as a target population. Therefore, homogeneous purposive sampling is used as a sampling method selection criteria. Out of 250 target population, 210 questionnaires were returned and processed which means an $84 \%$ response rate was achieved.

\subsubsection{Methods of Data Collection}

For the study, a survey was implemented for data collection. The survey consists of 45 items to be scored on a 6 point Likert Type Scale. The first section of the questionnaire was designed to reveal the demographics of the participants. The second part was designated to measure job satisfaction; therefore, the job satisfaction survey (JSS) by Spector (1994) was used. In his scale, Spector measures job satisfaction based on 9 facets using 36 questions where each facet has 4 questions. The third part was designed to measure an employee's job performance. The scale used to measure the job performance first developed by Choo (1986) and was later used by Ceylan et al. (2006). The job performance scale is based on outcomes and employee behaviours, using 9 questions.

\subsubsection{Reliability}

The reliability test was applied to examine the quality of the collected data. Cronbach alpha was administrated to test the stability of the scale. As shown in Table 1, 36 items of job satisfaction scale have a Cronbach's alpha level of 0.791 and 9 items of job performance scale have a Cronbach's alpha level of 0.730 , which indicates that the survey contains reliable items.

Table 1. Reliability Statistics

\begin{tabular}{lllll}
\hline Variables & $\begin{array}{l}\text { Cronbach's } \\
\text { Alpha }\end{array}$ & No. of Items & N & $\%$ \\
\hline Job Satisfaction & 0.791 & 36 & 210 & 100.0 \\
Job Performance & 0.730 & 9 & 210 & 100.0 \\
\hline
\end{tabular}

\section{ANALYSIS AND RESULTS}

The current research study uses a quantitative research method. It is used to answer questions on relationships within measurable variables to explain, predict and control phenomena (Streiner, 2003). The data collected for this research was coded concerning the different variables of the study to ease the process of data entry and data interpretation as proposed by Cooper and Schindler (2014). Data were entered into SPSS version 23, to evaluate descriptive statistics, frequencies, and percentages, and to provide analysis to answer the research questions posed. In Table 2, respondents' characteristic is given.

Table 2 : Descriptive Statistics of the Respondents

\begin{tabular}{llll}
\hline Valid & Demographics & Frequency & Percentage \\
\hline \multirow{3}{*}{ Gender } & Male & 104 & $49.5 \%$ \\
Total & Female & 106 & $50.5 \%$ \\
\cline { 2 - 4 } Age Groups & $18-24$ & 210 & $100.0 \%$ \\
& $25-34$ & 16 & $7.6 \%$ \\
& $35-44$ & 96 & $45.7 \%$ \\
Total & $45-54$ & 43 & $20.5 \%$ \\
& $55-64$ & 28 & $13.3 \%$ \\
& & 27 & $12.9 \%$ \\
\cline { 2 - 4 } Academic & High School & 210 & $100.0 \%$ \\
Degree & Diploma & 40 & $19.0 \%$ \\
Total & Associate Degree & 21 & $10.0 \%$ \\
\hline Job title & Bachelor & 84 & $9.5 \%$ \\
& Master Degree & 24 & $40 \%$ \\
& & 210 & $11.4 \%$ \\
\hline & Customer service & 88 & $100.0 \%$ \\
\hline & Sales and Marketing & 28 & $41.9 \%$ \\
& Cashier & 14 & $13.3 \%$ \\
& & & $6.7 \%$
\end{tabular}




\begin{tabular}{llll} 
& M\&E & 21 & $10.0 \%$ \\
& Cleaner & 20 & $9.5 \%$ \\
& Security Guard & 19 & $9.0 \%$ \\
\cline { 2 - 4 } Total & Driver & 20 & $9.5 \%$ \\
\cline { 2 - 4 } Overall & job & 210 & $100.0 \%$ \\
experience & $1-5$ & 114 & $54.3 \%$ \\
& $6-10$ & 37 & $17.6 \%$ \\
& $11-15$ & 16 & $7.6 \%$ \\
& $16-20$ & 19 & $9.0 \%$ \\
Total & 21 -above & 24 & $11.4 \%$ \\
\hline
\end{tabular}

In the sample, it is observed that $50.5 \%$ of the total respondents were female, while $49.5 \%$ of respondents were male. The majority of the participants were aged between $25-34.40 \%$ of the participants were holding a Bachelor's Degree. Besides, $41.99 \%$ of the respondents were holding customer service positions at work. At last, the majority of the participants were experienced between 1-5 years, which was $54.3 \%$.

\subsection{Correlation analysis}

To test the hypotheses of the study, the correlation analysis and multiple regression analysis are applied. The test results are revealed in the following tables:

Table 3: Correlation analysis between job satisfaction and performance

\begin{tabular}{|c|c|c|}
\hline & & Job Performance \\
\hline \multirow[t]{2}{*}{ Job satisfaction } & correlation (r) & $0.500^{\star \star}$ \\
\hline & $p$-value & 0.000 \\
\hline \multirow[t]{2}{*}{ Pay } & correlation (r) & $0.247^{* *}$ \\
\hline & $p$-value & 0.000 \\
\hline \multirow[t]{2}{*}{ Promotion } & correlation $(r)$ & $0.199^{* *}$ \\
\hline & $p$-value & 0.004 \\
\hline \multirow[t]{2}{*}{ Supervision } & correlation (r) & $0.254^{* *}$ \\
\hline & $p$-value & 0.000 \\
\hline \multirow[t]{2}{*}{ Fringe Benefits } & correlation (r) & $0.309^{\star *}$ \\
\hline & $p$-value & 0.000 \\
\hline \multirow[t]{2}{*}{ Contingent rewards } & correlation (r) & $0.276^{\star \star}$ \\
\hline & $p$-value & 0.000 \\
\hline \multirow[t]{2}{*}{ Operating Conditions } & correlation (r) & -0.132 \\
\hline & $p$-value & 0.056 \\
\hline \multirow[t]{2}{*}{ Co Workers } & correlation (r) & $0.568^{\star *}$ \\
\hline & $p$-value & 0.000 \\
\hline \multirow[t]{2}{*}{ Nature of work } & correlation $(r)$ & $0.385^{\star *}$ \\
\hline & $p$-value & 0.000 \\
\hline \multirow[t]{2}{*}{ Communication } & correlation (r) & $0.166^{*}$ \\
\hline & $p$-value & 0.016 \\
\hline
\end{tabular}

${ }^{*}$ Correlation is significant at the 0.05 level (2-tailed)

${ }^{* *}$ Correlation is significant at the 0.01 level (2-tailed) 
As stated in table 3, the correlation analysis clarifies that job satisfaction is significantly correlated with job performance $(r=.50 ; p<0.01)$. Therefore, $\mathrm{H} 1$ is supported and accepted. The correlation coefficient revealed that there is also a significant relationship between job performance and job satisfaction sub-dimension pay ( $p$ $<0.01$ ). Since the correlation coefficient $r$ is equal to $r>0.29$ it means they have a medium positive relation (Pallant, 2007). Thus, $\mathrm{H} 2$ is supported and accepted.

When it comes to the correlation between job performance and job satisfaction sub-dimension promotion, There is a significant relationship between two at the level of $1 \%$ with the $p$-value 0.004 and $r=0,199$. Thus, H3 is supported and accepted.

Also, there is a small positive significant relationship between job performance and job satisfaction subdimension supervision $(r=.25, \mathrm{p}<0.01)$. So, $\mathrm{H} 4$ is supported and accepted. Another result is given related to fringe benefits which there is a small positive significant relationship between job performance and job satisfaction fringe benefits sub-dimension $(r=.31, p<0.01)$. Thus, H5 is supported and accepted.

On the other hand, there is a medium positive significant relationship between job performance and job satisfaction contingent rewards sub-dimension $(r=.28, \mathrm{p}<0.01)$. Thus, $\mathrm{H} 6$ is supported and accepted. There is also a positive significant relationship between job performance and job satisfaction co-workers relationship sub-dimension with a large value $(r=.59, \mathrm{p}<0.01)$. So, $\mathrm{H} 8$ is supported and accepted. Lastly, there is a medium level relationship between job performance and job satisfaction nature of work sub-dimension $(r=.28, p<0.01)$. So, $\mathrm{H} 9$ is supported and accepted. At last, there is a small level positive significant relationship between job performance and job satisfaction communication sub-dimension $(r=.17, \mathrm{p}<0.05)$. So, $\mathrm{H} 10$ is supported and accepted. However, the correlation results revealed that in the case of there is no statistically significant relationship between job performance and job satisfaction operating conditions sub-dimension $(r=.-13$, $(p>0.05)$. So, H7 is rejected and unsupported.

\subsection{Regression analysis of the variables}

As shown in Table $4(a, b)$, this study tested a multiple linear regression analysis to examine the effect of the job satisfaction facets on job performance. The 9 facets of job satisfaction represent Adjusted R Square (R2). Accordingly, the 9 facets of job satisfaction were explained the job performance development of the MNC in Lesotho at the percentage of 66.8 (see in table 4 (a).

Table 4a. Model Summary

\begin{tabular}{lllll}
\hline Model & $\mathrm{R}$ & R Square & Adjusted R Square & Std. Error of the Estimate \\
\hline 1 & .662 & .438 & .412 & .42052 \\
\hline
\end{tabular}

From table 4 (b), we can see that the regression model is significant at the level of $1 \%$. Thus, the impact of job satisfaction facets is significant on the job performance of the MNC in Lesotho.

Table 4b. F Test Significant of the Regression

\begin{tabular}{lllllll}
\hline Model & & Sum of Squares & Df & Mean Square & $F$ & Sig. \\
\hline $\mathbf{1}$ & Regression & 27,527 & 9 & 3,059 & 17.296 & $.000^{*}$ \\
& Residual & 35,367 & 200 &, 177 & & \\
& Total & 62,894 & 209 & & & \\
& & & & &
\end{tabular}

\footnotetext{
* significant at the 0.01 level
}

Table 4c. Regression Analysis Coefficients

\begin{tabular}{|c|c|c|c|c|}
\hline & \multicolumn{4}{|c|}{ Coefficient } \\
\hline & Model & $B$ & $\mathrm{t}$ & Sig. \\
\hline \multirow[t]{4}{*}{1} & (Constant) & 1.213 & 4.157 & $.000^{* *}$ \\
\hline & pay & .033 & 1.031 & .304 \\
\hline & promotion & -.003 & -.100 & .920 \\
\hline & supervision & .026 & .879 & .380 \\
\hline
\end{tabular}




\begin{tabular}{cccc} 
fringebenefits & .087 & 2.244 & $.026^{*}$ \\
contingentrewards & .015 & .342 & .733 \\
operat.conditions & -.082 & -2.432 & $.016^{*}$ \\
coworkers & .303 & 7.165 & $.000^{* *}$ \\
nature & .142 & 2.843 & $.005^{\star *}$ \\
communication & .016 & .392 & .696 \\
\hline \multicolumn{2}{c}{ "significant at the 0.05 level } & ${ }^{* *}$ significant at the 0.01 level
\end{tabular}

The regression model which gives the relation between job satisfaction dimensions and job performance is estimated as seen in Eq.1.

$y=1.213+0.033 x_{1}-0.003 x_{2}+0.26 x_{3}+0.87 x_{4}+0.015 x_{5}-0.082 x_{6}+0.303 x_{7}+0.142 x_{8}+0.016 x_{9}$ Eq. 1

where the dependent variable is $y$ : job performance and independent variables are

$$
\begin{array}{r}
x_{1}: \text { pay } ; x_{2}: \text { promotion } ; x_{3} \text { : supervision } ; x_{4}: \text { fringebenefits } ; x_{5}: \text { contingentrewards } ; x_{6} \\
\quad \text { :operating conditions } ; x_{7}: \text { operating conditions; } x_{8}: \text { nature } ; x_{9}: \text { communication }
\end{array}
$$

In Table 4c, the coefficients of regression model and their significances are seen. So, as it is illustrated in the table as well, constant, nature of the work and co-workers relationship dimensions are significant at the 0.01 level and operating conditions and fringe benefits dimensions are significant at the 0.05 level. Among these variables fringe benefits, co-workers and nature of the work have positive relationship with the job performance. However, operating conditions has negative relationship with the job performance.

\section{CONCLUSIONS}

The purpose of this study was to investigate the relationship between job satisfaction and job performance in a multinational company in the least developed country, namely Lesotho. This study also examines the relationship between job satisfaction dimensions and job performance of the employees. It can be mentioned that employees of MNC Lesotho have a high level of job satisfaction in general. The results of the Pearson product-moment correlation revealed that job satisfaction is highly correlated with job performance. Therefore, $\mathrm{H} 1$ is supported and accepted. The correlation results also answer the fundamental research question proposed at the beginning of this research study as 'is there any correlation between job satisfaction and employees' job performance in an MNC in Lesotho?'.

The results of correlation analysis also revealed the significance and type of relationships between the nine job satisfaction dimensions and job performance. Accordingly, there is a medium positive significant relationship between job performance and job satisfaction pay, contingent rewards, and the nature of work sub-dimensions. Therefore, H2, H6, and $\mathrm{H} 9$ are all supported. Also, there is a large positive significant relationship between job performance and job satisfaction promotion and co-worker's sub-dimensions. Thus, $\mathrm{H} 3$ and $\mathrm{H} 8$ are supported as well. Lastly, there is a small positive relationship between job performance and job satisfaction supervision and communication dimensions. Therefore, $\mathrm{H} 4$ and $\mathrm{H} 10$ are supported. However, in contrast to these mentioned relationships, there is no statistically significant relationship between job performance and job satisfaction operating conditions sub-dimension. Therefore $\mathrm{H} 7$ is unsupported. The correlation results also answer the second research question of this study as 'Is there any relationship between job satisfaction dimensions (coworkers, supervision, the work itself, pay and promotion, operating procedures, communication, fringe benefits, and rewards) and employees' job performance in an MNC in Lesotho?'

The results are significant in support of previous researches of the same topic from a variety of ways. The importance of MNCs, especially in the least developed countries, has already been stated in this study's theoretical background. The fundamental points that might be underlined here again in terms of job satisfaction and job performance relationships are as follows; payment, feeling of security, chances of fair promotion and rewarding, creation of close social relationships and communication channels with and through supervisors and co-workers, fringe benefits for improving the life-conditions of employees, the regulated environment under the dimension of operating procedures (Kaur, 2013; Sentosa, 2012; Creswell, 2012; Wong and Laschinger, 2013). Currently, among these dimensions, all of them are supported and accepted within the scope of this study, except for the operating conditions dimension. There might be an effect of national culture differences related to the perception of rules and regulations and other operational conditional differences. Thus, it is required to be researched in the future studies of MNC in the least developed countries by considering national and cultural differences. 
The results of the study are beneficial to the subject of the research as being a guideline for those multinational companies in the least developed countries that are in pursuit of enriching their human resource management practices as a mechanism to develop global competence by considering national and organizational culture.

\subsection{Limitations and recommendations}

Although the researchers tried to design the whole study with attention, just like most studies conducted by various researchers there are also some limitations. The study has investigated the relationship between job satisfaction on job performance-limiting its area of research with one multinational company in Lesotho ${ }^{2}$. For this reason, it can be mentioned that the primary limitation is about the area and the population size of the study. The researcher's main focus was to investigate the impact of job satisfaction on job performance in multinational companies in the least developed countries, firstly, it would have been better to reach more population groups from at least two or more different countries, different backgrounds and different organizations. This would make it possible to measure the results of the study taking into account the impact of job satisfaction on job performance from employees from different multinational companies, different cultural and environmental backgrounds. Secondly, it would have been better to have a larger sample size which could have used parametric tests that may have produced different results from the current study. Therefore, one suggestion for future researches would be to survey a larger scale that includes more multinational companies and larger sample sizes.

Additionally, the study recommends that there is a need to cover more multinational companies in the least developed countries, with different races, cultures and environmental background as the research findings might be different as compared to the survey conducted in one country. Furthermore, the researcher suggests that future studies should analyse the population using different test instruments and compare the results and research findings with this study.

\section{ACKNOWLEDGEMENTS}

We would like to thank Assoc. Prof. Pınar Kaya Samut for her insightful comments that benefited the paper. This study is a part of the first author's unpublished master thesis

\section{REFERENCES}

Ali, A. A., Edwin, O., \& Tirimba, O. I. (2015). Analysis of Extrinsic Rewards and Employee Satisfaction: case of Somtel Company in Somaliland. International Journal of Business Management \& Economic Research, 6(6), 417-435

Ahmad, M. B., Wasay, E., \& Malik, S. U. (2012). Impact of Employee Motivation on Customer Satisfaction: Study of Airline Industry in Pakistan. Interdisciplinary Journal of Contemporary Research in Business, 4(6), 531-539

Ali, A., \& Haider, J. (2012). Impact of internal organizational communications on employee job satisfaction-Case of some Pakistani Banks. Global Advanced Research Journal of Management and Business Studies, 1(10), 38-44.

Amin, M., Aldakhil, A. M., Wu, C., Rezaei, S., \& Cobanoglu, C. (2017). The structural relationship between TQM, employee satisfaction and hotel performance. International Journal of Contemporary Hospitality Management, 29 (4), 1256 - 1248

Anitha, J. (2014). Determinants of employee engagement and their impact on employee performance. International Journal of Productivity and Performance Management, 63(3), 308-323

Baharin, I., \& Sentosa, I. (2012). Sustainable Development and Multinational Business.IOSR Journal of Business and Management, 1(3), 50-56

Bakotić, B. (2016). Relationship between job satisfaction and organizational performance. Economic Research-Ekonomska Istraživanja, 29 (1),118-130

Ceylan, A. \& Ulutürk, H. (2006). Rol belirsizliği, rol çatışması, iş tatmini ve performans arasındaki ilişkiler, Doğuş University Journal, (7), 48-58

Cobb, B. (2004). Assessing job satisfaction and emotional intelligence in public school teachers, B.A.Thesis, Department of Psychology, Western Kentucky University. Available at https://digitalcommons.wku.edu/cgi

Cooper, D. R., \& Schindler, P. S. (2014). Business Research Methods, $12^{\text {th }}$ Ed. New York, New York: McGraw-Hill

Currivan, D.B. (1999). The causal order of job satisfaction and organizational commitment in models of employee turnover. Human resource Management review, 9 (4), 495-524

De Schutter, O. (Ed.) (2005). Transnational Corporations and Human Rights, United Kingdom, Hart Publishing, Oxford

Dugguh, S., \& Dennis, A. (2014). Job satisfaction theories: Traceability to employee performance in

\footnotetext{
2 The reason for choosing only one company for conducting the study is that the ease of access and time limitation. Besides, the other reason for the smaller sample size being in Lesotho as a country has only 2 million population with only $27 \%$ of the whole population living in the urban areas and the rest of the population lives in the rural areas with no jobs.
} 
Organizations. IOSR Journal of Business and Management, 16 (5),11-18

Fluegge-Woolf, E.R. (2014). Play hard, work hard: Fun at work and job performance, Management Research Review, 3 (8), 682-705

Fobete, D.N. (2013). Multinational Corporation and Third World Development GRIN, Verlag

Fok, R. H., \& Yeung, R. M. (2016). Work attitudes of Generation Y in Macau's hotel industry:

Management's perspective. Worldwide Hospitality and Tourism Themes, 8 (1), 83-96

Garrin, J. (2014). Self-efficacy, self-determination, and self-regulation: The role of the fitness professional in social change agency. Journal of Social Change, 6 (1),41-54

Greer, J., \& Singh, K. (2002). A Brief History of Transnational Corporations, Global Policy Forum

Gregory,B.T., Harris,S.T., Armenakis,A.A. \& Shook, C.L. (2009). Organizational culture and effectiveness:

A study of values, attitudes, and organizational outcomes. Journal of Business Research, 62 (7),673- 679

Gupta, M. (2014). Employees Satisfaction towards Monetary Compensation Practices. Global Journal of Finance and Management, 6 (8), 757-764

Hansen, M.W., \& Gwozdz, W. (2013). What makes MNCs succeed in developing countries: An empirical analysis of subsidiary performance. CBDS Working Paper Series

Hellqvist,N.(2011).Global performance management: A Research Agenda. Management Research Review, 34 (8), $927-946$

Haile, M. \& Premanandam, P. (2017). Employees' job satisfaction in Ethiopia: A Comparative study of selected public and private sectors in Woldia district. International Journal of Applied Research, 3 (4), 19-25

Imran, R. Majeed, M. \& Ayub, A. (2015). Impact of Organizational Justice, Job Security and Job satisfaction on Organizational Productivity. Journal of Economics, Business and Management, 3 (9), 840-845

Javed, M., Balach \& Hassan, F. (2014). Determinants of Job Satisfaction and its impact on employee Performance and Turnover Intentions. International Journal of Learning \& Development, 4 (2), 120-140

Jin, H. (2017). Multinational Corporations and EU Economic Integration. Centria University of Applied Sciences Business Management

Klaus, A.R \& Cregan, C. (2017). Cosmetic facial surgery: the influence of self-esteem on job satisfaction

and burnout. Asia Pacific Journal of Human Resources, (5), 320-336

Kaur, A. (2013). Maslow's Need Hierarchy Theory: Applications and Criticisms. Global Journal of

Management and Business Studies, 3(10), 1061-1064

Kehoe, R. R., \& Wright, P. M. (2013).The impact of high-performance human resource practices on employees' attitudes and behaviours. Journal of Management, 39 (2), 366 - 391

Kemoh, L, M. (2016). The Impact of Motivation on Employees Performance in an Organization: A Case of UNICEF, Somalia Support Centre, Nairobi.

Kosteas, V.D. (2011). Job Satisfaction and promotions. Industrial Relations: A Journal of Economy and Society, 50(1),174 $-194$

Linz, S.J., \& Semykina, A. (2012). What makes workers happy? Anticipated rewards and job satisfaction. Industrial relations: A Journal of Economy and Society, 51(84),11-84

Locke, E. A. (1976). The Nature and Causes of Job Satisfaction. In M. D. Dunnette (Ed). Handbook of industrial and organizational psychology, Chicago, IL: Rand.

Miah, M., \& Hafid, N. (2019). A Review Study of the Human Resource Management Practices on Job Satisfaction of Hotel Industry Employees of Malaysia. International Journal of Human Resource Studies, 9 (3),75-85

Millán, J. M., Hessels, J., Thurik, R., \& Aguado, R. (2013). Determinants of job satisfaction: A European comparison of selfemployed and paid employees. Small Business Economics, 40 (3), 651-670

Muchemi, T. W. (2015). Factors Affecting Employee Satisfaction in Non-Governmental Organizations: A Case Study of Africa Yoga Project. Unpublished Doctoral dissertation, United States International University-Africa. Available at http://erepo.usiu.ac.ke/11732/707

Mukul, A, Z., Rayhan, J, S., Hogue, F., \& Islam, F (2013). Job characteristics model of Hackman and Oldham in garment sector in Bangladesh: a case study at Saver area in Dhaka district. International Journal of Economics, Finance and Management Sciences, 1 (4),188-195

Musyoka, S. (2015). Effect of Staff Welfare Programs on Employee Satisfaction among Commercial Banks in Kenya, Doctoral Dissertation, United States International University-Africa

Omondi, C. (2015). Parent-Subsidiary Relationship and How It Affects Performance in Telkom Kenya (Orange), MBA thesis. Nairobi: $\quad$ University of $\quad$ Nairobi. Available at https://pdfs.semanticscholar.org/e6da/04996312b7f15256ae2c09383da143f7addf.pdf

Pandey, J. (2019). Factors Affecting job performance: An Integrative Review of Literature. Management Research Review, 42 (2), 263-289

Pan, F. C. (2015). Practical application of importance-performance analysis in determining critical job satisfaction factors of a tourist hotel. Tourism Management, 46, 84-91 
Pergamit, M. R., \& Veum, J. R. (1999). What is a promotion? Industrial and Labor Relations Review, 52(4), 581-601

Peng, Y.P. (2014). Job satisfaction and job performance of university librarians: A disaggregated

Examination. Library and information research, 36 (1), 74-82

Piekkari, R., \& Zander, L. (2005). Language and communication in international management. International Studies of Management and Organization, 35 (1), 3 - 9

Pradhan, R. K., \& Jena, L. K. (2017). Employee performance at workplace: Conceptual model and empirical validation. Business Perspectives and Research, 5(1), 69-85.

Rosete, D. (2006). The impact of organizational values and performance management congruency on satisfaction and commitment. Asia Pacific Journal of Human Resources, 44(1),7-24

Shields, M., \& Price, S. (2002). Racial harassment, job satisfaction and intention to quit: Evidence from British Nursing Profession. Economica, 69 (3), 295 -362

Singh,S.K., \& Singh, A.P. (2019). Interplay of organizational justice, psychological empowerment, organizational citizenship behaviour, and job satisfaction in the context of circular economy. Management Decision, 57 (4), 937 - 952

Singh J., \& Jain, M. (2013). A Study of Employees' Job Satisfaction and Its Impact on their Performance. Journal of the Indian Research, 4, 105-111

Steel, P., Schmidt, J., Bosco, F., \& Uggerslev, K. (2019). The effects of personality on job satisfaction and life satisfaction: A meta-analytic investigation accounting for bandwidth-fidelity and commensurability. Human Relations, 72(2), 217247

Spector, P.E. (1994). Job Satisfaction Survey, Tampa, FL: Department of Psychology, University of South Florida.

Streiner, D. L. (2003). Starting at the Beginning: An Introduction to Coefficient Alpha and Internal

Consistency. Journal of Personality Assessment, 80 (1), 99-103

Thahier, R., Ridjal, S., \& Risani, F. (2014). The influence of leadership style and motivation upon employee

performance in the provincial secretary office of West Sulawesi. International Journal of Academic Research, 6 (1),116-124

Taris,T.W., \& Schreurs,P.S. (2009). Well-being and organizational performance: An organizational-level

test of the happy-productive worker hypothesis. Work \& Stress, 23 (2),120 - 136

Thornbecke, W.,\& Salike,N. (2014). Understanding foreign direct investment in East Asia. ADBI Working Papers, No. 290. Available at https://www.adb.org/sites/default/files/publication/156145/adbi-wp290.pdf

Tüzün, İ.K. (2013).Organizational Levels of Analysis of Communication Satisfaction and Identification

in Relation to Job Satisfaction. Journal of Economics, Business and Management, 1(1), 1-5

Valaei, N. \& Rezai, S. (2016). Job Satisfaction and organizational commitment: An Empirical Investigation among ICTSMEs. Management Research Review, 39 (2),1663-1694

Williams, H.L.,Costley,T.,Bellury, L.M. \& Moobed, J. (2018). Do health promotion behaviours affect levels of job satisfaction and job stress for nurses in an acute care hospital? The Journal of Nursing Administration, 48 (6),342-348

Wattoo, M.A. (2019). High-performance work systems and work-family interface: job autonomy and self-efficacy as mediators. Asia Pacific Journal of Human Resources, retrieved from https://onlinelibrary.wiley.com/doi/abs/10.1111/1744-7941.12231

Wong. C.A., \& Laschinger, H.K.S. (2013). Authentic leadership, performance, and job satisfaction: the mediating role of empowerment. Journal of Advanced Nursing, 69 (4), 947-959

Yousaf, S., Latif, M., Aslam, S., \& Saddiqui, A. (2014). Impact of financial and nonfinancial rewards on employee motivation. Middle-East journal of scientific research, 21(10),1776-1786.

Zikmund, W. G., Babin, B. J., Carr, J. C. \& Griffin, M. (2014). Business research methods. Cengage Learning.

Zinal. M. B. (2016). The Effect of Training on Employee's Performance. Unpublished Master Dissertation. Netherlands Bureau for Economic Policy Analysis. 